\title{
Esophageal Stricture Caused by the Ingestion of Undissolved Picosulfate Powder
}

\author{
Daehyun Kim', Byungha Cho', Jong Wook Choi', Ki Bae Kim ${ }^{1}$ and Seon Mee Park ${ }^{1,2}$ \\ ${ }^{1}$ Department of Internal Medicine, Chungbuk National University Hospital, Cheongju, ${ }^{2}$ Department of Internal Medicine, Chungbuk National \\ University College of Medicine, Cheongju, Korea
}

Picosulfate solution is widely used as a small volume bowel cleansing agent and is considered to be effective and relatively safe. A case of a 75-year-old woman ingested picosulfate powder and drank a small volume of water, subsequently experienced severe burning pain in the chest. Endoscopy was performed and showed a submucosal hemorrhage and exudative ulcers at the mid to lower esophagus. At 2 weeks, her symptoms improved with conservative treatment. However, liquid food dysphagia developed 11 weeks after ingestion. A follow-up endoscopy revealed multiple esophageal strictures, which were treated with a fully covered metal stent and esophageal balloon dilation. Consequently, the esophageal strictures improved after one year. As this case demonstrates, detailed information about picosulfate powder ingestion after dissolving it in more than $200 \mathrm{~mL}$ of water should be presented to patients to avoid esophageal injury. Clin Endosc 2021;54:122-126

Key Words: Caustic esophageal injury; Esophageal stricture; Patient education; Picosulfate

\section{INTRODUCTION}

Polyethylene glycol and picosulfate (Picolight powder; Pharmbio, Seoul, Korea) are equally effective bowel cleansers that are widely used in colonoscopy procedures. ${ }^{1}$ However, picosulfate powder is easier to administer because of its orange flavor and smaller liquid volume requirement. When picosulfate powder is dissolved in water, magnesium oxide and citric acid combine to form magnesium citrate, which acts as an osmotic laxative, and sodium picosulfate as a stimulant laxative. ${ }^{2}$ Picosulfate powder must, therefore, be completely dissolved in water and cooled before drinking because it produces an exothermic reaction, which occurs immediately after the substance comes into contact with water. ${ }^{3}$ Six cases ${ }^{3-8}$ of corrosive

Received: October 25, 2019 Revised: December 22, 2019

Accepted: December 23, 2019

Correspondence: Seon Mee Park

Department of Internal Medicine, Chungbuk National University College of Medicine, 776 1Sunhwan-ro, Seowon-gu, Cheongju 28644, Korea

Tel: +82-43-269-6019, Fax: +82-43-273-3252, E-mail: smpark@chungbuk.ac.kr ORCID: https://orcid.org/0000-0002-5835-2741

(c) This is an Open Access article distributed under the terms of the Creative Commons Attribution Non-Commercial License (http://creativecommons.org/ licenses/by-nc/3.0) which permits unrestricted non-commercial use, distribution, and reproduction in any medium, provided the original work is properly cited. mucosal injuries on the oropharynx, esophagus, or stomach caused by undissolved sodium picosulfate powder have been reported, all of which improved without further complications. ${ }^{3-8}$ The development of esophageal strictures from corrosive esophageal injury has never been previously reported. Nevertheless, this report presents a case of esophageal stricture following corrosive esophagitis from undissolved picosulfate powder.

\section{CASE REPORT}

A 75-year-old woman came to our emergency department with severe sore throat and chest pain during food ingestion. One week previously, she had scheduled an esophagogastroduodenoscopy (EGD) and colonoscopy at her medical checkup. She was prescribed picosulfate powder as a colon cleansing agent with detailed education about the ingestion method. However, she took the powder and drank a small amount of water afterwards because she thought that would be easier than dissolving it. Immediately right after, a burning sensation developed in her chest. Ten hours later, she went to her follow-up appointment and was performed EGD, which showed 
a submucosal hemorrhage, ulcerative lesions, and spotty necrosis along the entire esophagus and corresponding mild erythematous lesions in the stomach (Fig. 1). She did not disclose her mistake and refused the physician's advice for admission. For the next 7 days, she stayed at home, followed a liquid diet, and took pain killers. However, her symptoms worsened; thus, she visited our hospital. Her laboratory tests were normal, however, an emergent EGD revealed presence of diffuse ulcers with yellowish exudate throughout the esophagus (Fig. 2A-D). An endoscopic biopsy showed esophageal ulcers and candidiasis (Fig. 2E), nonetheless, she tested negative for Helicobacter pylori infection. A neck computed tomography (CT) scan revealed esophageal edema and increased wall enhancement (Fig. 2F). We treated her with fasting and parenteral nutrition, fluconazole $100 \mathrm{mg}$ once daily for 10 days, and a parenteral proton pump inhibitor, pantoprazole $40 \mathrm{mg}$ twice daily. After one week of admission, she complained of dysphagia with solid foods. A follow-up EGD revealed multiple ulcers and scars at the mid esophagus and a $25 \mathrm{~cm}$ luminal stricture from the upper incisor (UI) (Fig. 3A) although her candidiasis had resolved. After two weeks of admission, the patient's chest pain was endurable, and she could tolerate a liquid diet. However,
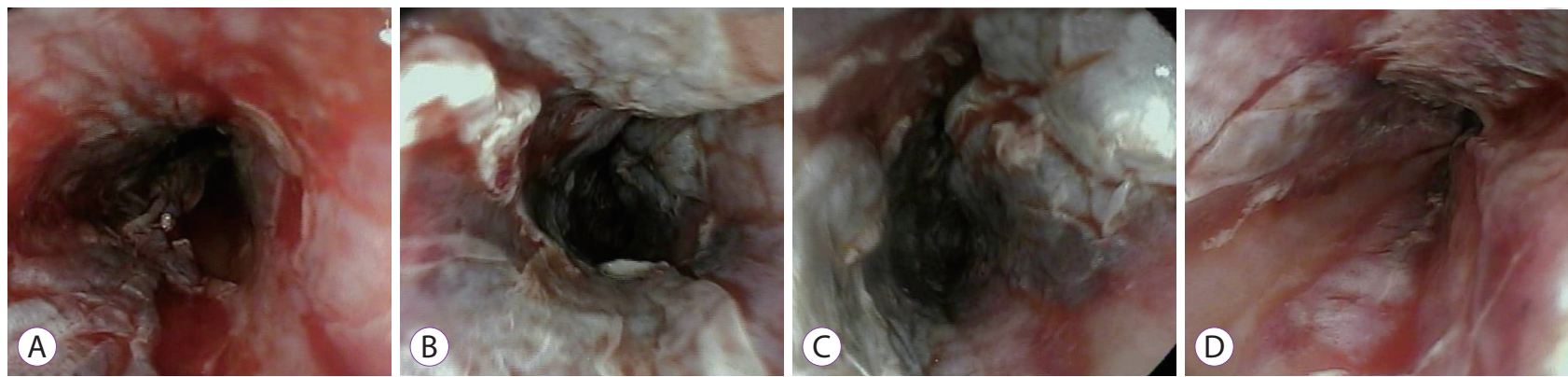

Fig. 1. Endoscopic findings at 1 day after ingestion of picosulfate powder. Endoscopy reveals submucosal hemorrhage, ulcerative lesions, and spotty necrosis along the whole esophagus. Caustic injury is more severe in the mid esophagus $(B, C)$ than the upper $(A)$ or lower (D) parts.
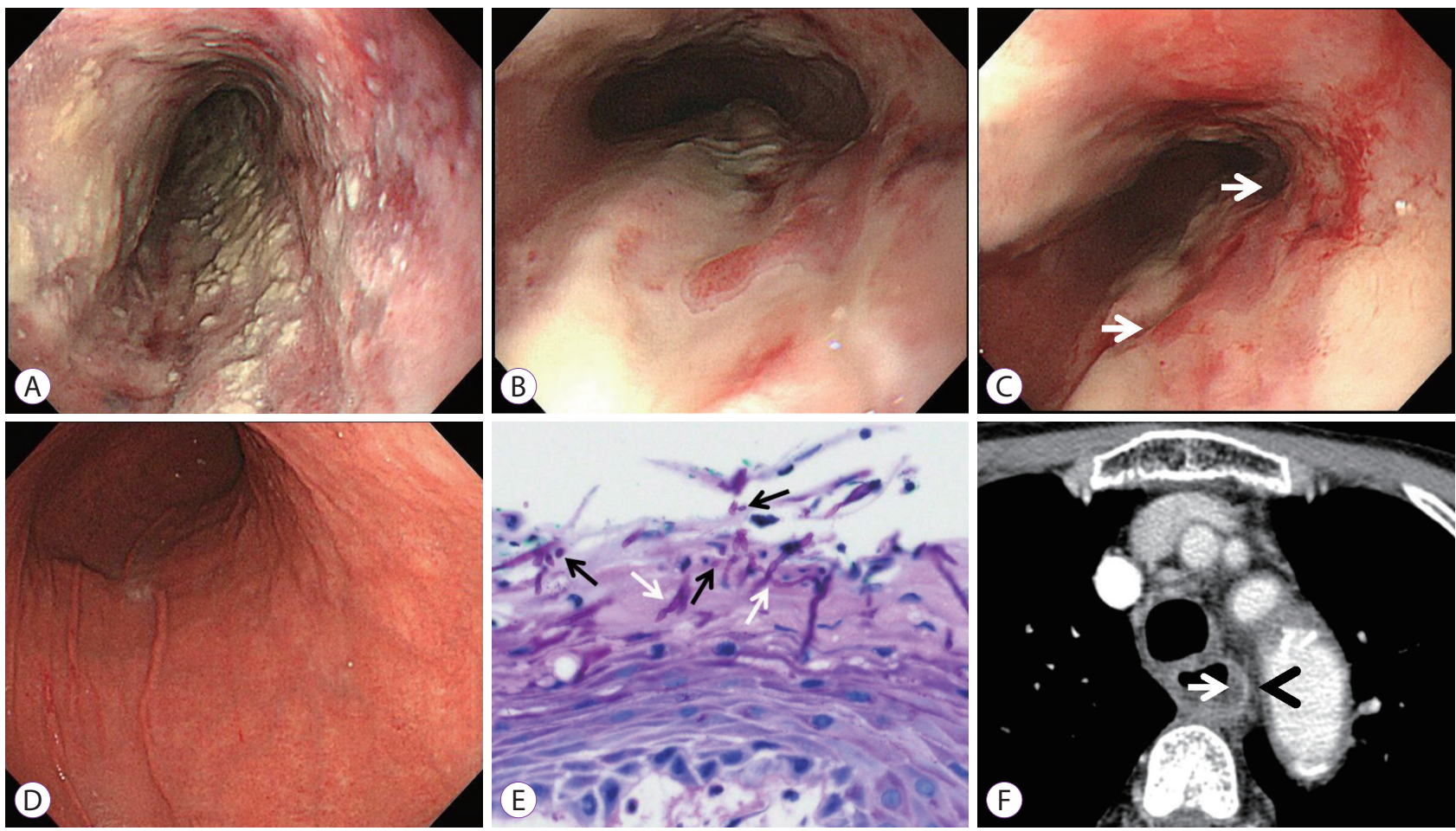

Fig. 2. Image findings at 1 week after ingestion. Endoscopy reveals diffusely scattered yellowish exudates (A), mucosal sloughing (B), and multiple ulcers (C, arrows) throughout the esophagus and linear erythematous lesions in the stomach (D). An endoscopic biopsy (E) shows fungal pseudohyphae (white arrows) and a few yeasts (black arrows) in the esophageal mucosa on PAS stain (original magnification, X400). A neck CT scan (F) reveals esophageal edema (arrow) and increased wall enhancement (arrowhead). 
11 weeks after the picosulfate powder ingestion, she developed liquid food dysphagia. An ultrathin EGD revealed severe esophageal strictures ranging from $25-30 \mathrm{~cm}$ from the UI (Fig. 3B). Consequently, esophageal stenting was performed using a $10 \mathrm{~cm}$ fully covered metal stent (Hanarostent; M.I. Tech, Pyeongtaek, Korea) through the scope (Fig. 3C). The esophageal stenosis was relieved after the stent was indwelling for 3 months (Fig. 3D). However, restenosis occurred 4 weeks later (Fig. 4A). We treated this with esophageal balloon dilation using a $20 \mathrm{~mm}$ controlled radial expansion balloon catheter (Microvasive; Boston Scientific Co., Natick, MA, USA) (Fig. 4B, C). The esophageal strictures improved after one year (Fig. 4D), and she was monitored for more than 3 years afterwards without symptoms.

\section{DISCUSSION}

Caustic ingestion can cause severe esophageal and gastric injury. Tissue injury caused by corrosive alkaline and acidic substances vary depending on the type, quantity, concentration, and contact time. ${ }^{9}$ Acidic agent-driven corrosive esophagitis is rare; however, it can lead to a similar ${ }^{10}$ or sometimes worse outcome ${ }^{9}$ than that induced by alkaline agents.

Picolight is dispensed in a powder form (sodium picosulfate $0.01 \mathrm{~g}$, magnesium oxide $3.5 \mathrm{~g}$, citric acid $12 \mathrm{~g}$ per sachet).
Magnesium oxide and citric acid form magnesium citrate when the powder is dissolved in water. It is metabolized by gut bacteria into the active compound 4,4'-dihydroxydiphenyl-(2-pyridiyl)-methane, ${ }^{2}$ which is a stimulant laxative that increases bowel peristalsis and mucosal secretions and blocks water absorption in the intestine. ${ }^{2}$ However, when picosulfate is dissolved in water, it induces an exothermic reaction that can cause chemical burning in the gastrointestinal tract mucosa. $^{3-8}$ To prevent Picolight-associated tissue injury, dissolution of this powder in more than $200 \mathrm{~mL}$ of water is strongly recommended. ${ }^{2}$ On the other hand, dissolving it in a low volume of water results in a more acidic liquid, which can lead to corrosive esophageal injury.

Six cases of corrosive injuries in the oropharynx, ${ }^{6}$ esophagus, $^{3,5,8}$ or stomach ${ }^{3-5,7}$ caused by partially dissolved or undissolved picosulfate powder have been reported (Table 1). The most common symptoms were burning sensations or pain in the throat, epigastrium, or chest, with hematemesis ${ }^{5,8}$ or hoarseness ${ }^{6}$ also occurring in some cases. The injury sites were determined by where the picosulfate powder is attached to. In one case, airway obstruction developed from oropharyngeal injury, which required endotracheal intubation. ${ }^{6}$ In another case, the patient drank a large quantity of water immediately afterward, leading to acute gastric ulceration; however, no esophageal injury was noted. ${ }^{7}$ All cases were conservatively treated with fasting, parenteral nutrition, and proton pump
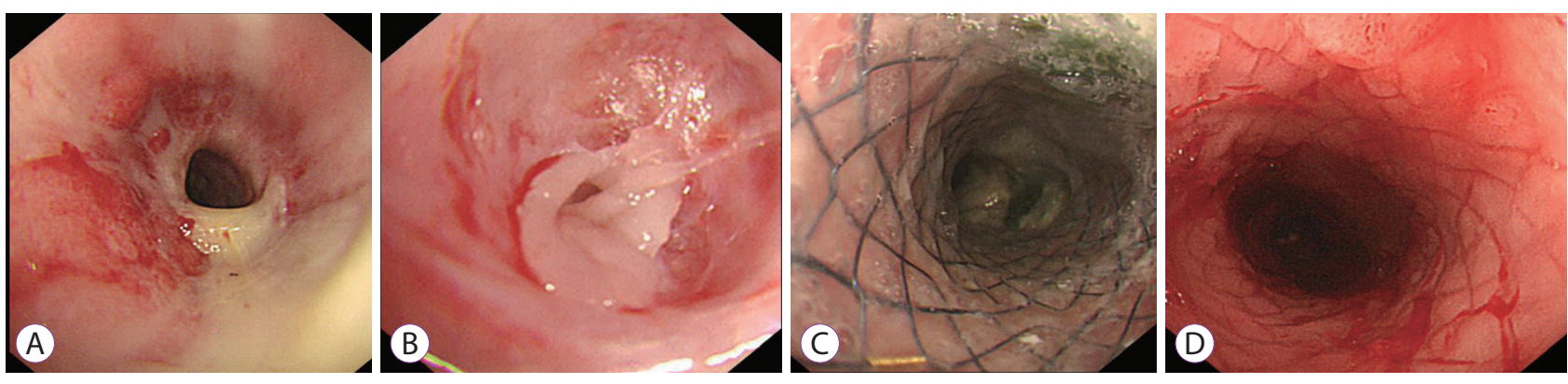

Fig. 3. Endoscopic findings at 2 weeks and 11 weeks after ingestion. Luminal narrowing and esophageal ulcers covered with exudates at 2 weeks (A). The narrowest part of the esophageal stricture (B) caused by healed ulcer scars at 11 weeks after ingestion. Esophageal stricture was treated with fully covered metal stenting for 3 months (C, D).
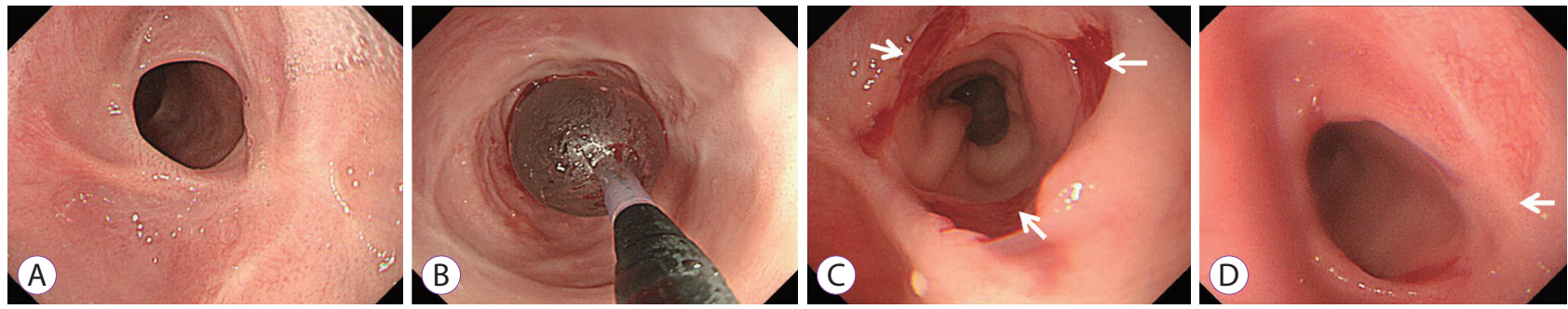

Fig. 4. Endoscopic findings at 8 months and 12 months after ingestion. Restenosis at the mid esophagus after stenting $(A)$ is treated with esophageal balloon dilation (B). Luminal stenosis relief by mucosal tearing (C, arrows) and remaining ulcer scars (D, arrow). 
inhibitors, with additional empirical antibiotics in some cases. $^{3-8}$ The three cases involving the esophagus ${ }^{3,5,8}$ did not progress to esophageal strictures. Therefore, partially dissolved powder, ingestion of large volumes of water afterward, or early treatment may reduce the risk of esophageal stricture development. ${ }^{3-8}$ Conversely, in the present case, severe esophageal injury progressed to an esophageal stricture. Despite severe mucosal injury to the entire esophagus, treatment was delayed by 1 week. Additionally, the second EGD 1 week after ingestion revealed esophageal candidiasis in addition to extensive esophageal ulcers. Although chest pain improved two weeks after treatment, liquid food dysphagia occurred 11 weeks after ingestion as a result of the stricture formation. Therefore, drinking a small volume of water after ingestion and delaying treatment may induce severe mucosal injury and esophageal stricture. Hence, we perceive that the esophageal candidiasis did not influence the development of the esophageal stricture in this case, because it is a superficial infection and was easily treated using fluconazole.

An early endoscopy is a safe, reliable, and accurate diagnostic tool. ${ }^{11}$ It is necessary since the mucosal injury grading is crucially significant for the management and prognosis of esophageal injuries. ${ }^{12}$ Of the various endoscopic grading systems, Zargar classification is most commonly used. ${ }^{11}$ Corrosive esophageal injuries of grade I (edema and erythema of the mucosa) and grade IIA (hemorrhage, erosions, blisters, and superficial ulcers) heal completely without sequelae. However, up to $70 \%$ of patients with grade IIB (circumferential

Table 1. Cases of Corrosive Mucosal Injuries Caused by Sodium Picosulfate Powder Ingestion

\begin{tabular}{|c|c|c|c|c|c|c|c|c|c|}
\hline \multirow{2}{*}{ Study } & \multirow{2}{*}{$\begin{array}{l}\text { Age/ } \\
\text { Sex }\end{array}$} & \multirow{2}{*}{$\begin{array}{l}\text { Clinical } \\
\text { symptoms }\end{array}$} & \multicolumn{3}{|c|}{ Image findings } & \multirow{2}{*}{ Histology } & \multirow{2}{*}{ Treatment } & \multirow{2}{*}{$\begin{array}{l}\text { Time to } \\
\text { resolve }\end{array}$} & \multirow{2}{*}{$\begin{array}{c}\text { Follow- } \\
\text { up }\end{array}$} \\
\hline & & & Oropharynx & Esophagus & Stomach & & & & \\
\hline $\begin{array}{l}\text { Suh et al. } \\
\qquad(2014)^{3}\end{array}$ & $68 / \mathrm{F}$ & $\begin{array}{l}\text { Heartburn, } \\
\text { epigastric } \\
\text { pain }\end{array}$ & Normal & $\begin{array}{l}\text { Longitudinal } \\
\text { vesicles with } \\
\text { hemorrhagic } \\
\text { content }\end{array}$ & $\begin{array}{l}\text { Multiple } \\
\text { longitudinal } \\
\text { confluent } \\
\text { ulcers (GC of } \\
\text { body) }\end{array}$ & $\begin{array}{l}\text { Inflammatory } \\
\text { exudates } \\
\text { with fibrin } \\
\text { and inflam- } \\
\text { matory cells }\end{array}$ & N/A & N/A & N/A \\
\hline $\begin{array}{l}\text { Lee et al. } \\
\qquad(2014)^{4}\end{array}$ & $64 / F$ & $\begin{array}{l}\text { Heartburn, } \\
\text { epigastric } \\
\text { pain }\end{array}$ & Normal & Normal & $\begin{array}{l}\text { Many vesicles } \\
\text { (GC of body) }\end{array}$ & $\mathrm{N} / \mathrm{A}$ & $\begin{array}{l}\text { Almagate, } \\
\text { Lafutidine, } \\
\text { liquid diet }\end{array}$ & 3 days & $1 \mathrm{mo}$ \\
\hline $\begin{array}{l}\text { Seo et al. } \\
(2015)^{5}\end{array}$ & $48 / \mathrm{M}$ & $\begin{array}{l}\text { Hemateme- } \\
\text { sis }\end{array}$ & Normal & $\begin{array}{l}\text { Diffuse linear } \\
\text { mucosal breaks } \\
\text { with exudates }\end{array}$ & $\begin{array}{l}\text { Linear ulcers } \\
\text { with hematins } \\
\text { (GC of body) }\end{array}$ & $\mathrm{N} / \mathrm{A}$ & $\begin{array}{l}\text { TPN, PPIs, } \\
\text { antibiotics }\end{array}$ & 7 days & $5 \mathrm{mo}$ \\
\hline $\begin{array}{l}\text { Kim et al. } \\
(2016)^{6}\end{array}$ & $59 / \mathrm{M}$ & $\begin{array}{l}\text { Sore throat, } \\
\text { hoarseness }\end{array}$ & $\begin{array}{l}\text { Diffuse } \\
\text { mucosal } \\
\text { swelling } \\
\text { and erosion }\end{array}$ & $\begin{array}{c}\text { Mild } \\
\text { hyperemia }\end{array}$ & Normal & N/A & $\begin{array}{l}\text { Endotracheal } \\
\text { intubation, } \\
\text { intravenous } \\
\text { steroid, tra- } \\
\text { cheostomy }\end{array}$ & 21 days & $1 \mathrm{mo}$ \\
\hline $\begin{array}{l}\text { Ze et al. } \\
\qquad(2017)^{7}\end{array}$ & $69 / \mathrm{M}$ & $\begin{array}{l}\text { Epigastric } \\
\text { pain }\end{array}$ & Normal & Normal & $\begin{array}{l}\text { Multiple } \\
\text { longitudinal } \\
\text { ulcers (body, } \\
\text { antrum) }\end{array}$ & $\begin{array}{l}\text { Infiltration of } \\
\text { lymphoid } \\
\text { cells and } \\
\text { neutrophils } \\
\text { intermingled } \\
\text { with hemor- } \\
\text { rhage }\end{array}$ & PPIs & 7 days & $6 \mathrm{wk}$ \\
\hline $\begin{array}{l}\text { Yang et al. } \\
(2017)^{8}\end{array}$ & $56 / \mathrm{M}$ & $\begin{array}{l}\text { Chest pain, } \\
\text { hemateme- } \\
\text { sis }\end{array}$ & $\begin{array}{l}\text { Swollen epi- } \\
\text { glottis }\end{array}$ & $\begin{array}{l}\text { Diffuse edema- } \\
\text { tous and friable } \\
\text { mucosa, deep } \\
\text { ulceration and } \\
\text { hemorrhage }\end{array}$ & Normal & N/A & $\begin{array}{l}\text { Fasting, TPN, } \\
\text { antibiotics, } \\
\text { PPIs }\end{array}$ & $1 \mathrm{mo}$ & $1 \mathrm{mo}$ \\
\hline $\begin{array}{l}\text { Present } \\
\text { case }\end{array}$ & $75 / \mathrm{F}$ & $\begin{array}{l}\text { Chest pain } \\
\text { (early), } \\
\text { dysphagia } \\
\text { (late) }\end{array}$ & Normal & $\begin{array}{l}\text { Diffuse friable } \\
\text { mucosa, hemor- } \\
\text { rhage and focal } \\
\text { necrosis }\end{array}$ & Mild hyperemia & $\begin{array}{l}\text { Infiltration of } \\
\text { lymphoid } \\
\text { cells and } \\
\text { neutrophils, } \\
\text { candidiasis }\end{array}$ & $\begin{array}{l}\text { Fasting, TPN, } \\
\text { PPIs, fluco- } \\
\text { nazole }\end{array}$ & $\begin{array}{l}\text { Early: } \\
2 \mathrm{wk} \\
\text { Late: } \\
1 \mathrm{yr}\end{array}$ & $3 \mathrm{yr}$ \\
\hline
\end{tabular}

GC, greater curvature; N/A, not available; PPIs, proton pump inhibitors; TPN, total parenteral nutrition. 
lesion) and more than $90 \%$ of patients with grade III (focal or extensive deep gray or brownish-black ulcers) are likely to develop esophageal strictures or gastric scarring. ${ }^{11,12}$ In this case, the patient was diagnosed with a grade IIIA esophageal injury since there were deep ulcers and focal necrosis that progressed to esophageal strictures. In addition to an endoscopy, a CT-based classification of esophageal corrosive injuries was a reliable tool for predicting long-term complications. ${ }^{13}$ After 7 days, present case was characterized as grade II since there was wall and soft tissue edema but with increased wall enhancement.

There is no consensus about the ideal timing and method of endoscopic management of corrosive esophageal injury. ${ }^{14} \mathrm{En}$ doscopic dilation with bougination or ballooning is generally recommended as first line treatment, and esophageal stents are used for caustic strictures resistant to dilation. ${ }^{14}$ However, a recent study reported that esophageal dilation for caustic esophageal injury failed in three-fourths of the patients studied, and that long stricture length is a risk factor for failure. ${ }^{15}$ Therefore, we treated this case conservatively during the acute phase of esophageal injury without stricture prevention procedures. Intralesional steroid injections or topical mitomycin have been reported as adjunctive endoscopic treatment options for complex strictures. ${ }^{16}$ However, we treated the esophageal stricture using esophageal stenting instead of bougination or balloon dilation because there was a high risk of perforation in this case. Recent data revealed that esophageal stents should be removed within 12 weeks and clinical success with caustic strictures was $35 \%-45 \%$ with a migration rate of $25 \%-35 \% .^{17}$ In this case, re-stenosis developed following the stent removal that eventually improved with esophageal balloon dilation.

We reported a case of esophageal stricture caused by undissolved picosulfate powder that the patient accidentally took. As this case demonstrates, detailed information emphasizing that undissolved picosulfate powder induces corrosive esophageal injury should be provided to patients.

Conflicts of Interest

The authors have no potential conflicts of interest.

Funding

None.

\section{Author Contributions}

Conceptualization: Seon Mee Park

Data curation: Daehyun Kim

Methodology: Byungha Cho, Jong Wook Choi

Supervision: SMP
Visualization: Ki Bae Kim

Writing-original draft: DK

ORCID
Daehyun Kim:

Byungha Cho:

Jong Wook Choi:

Ki Bae Kim:

Seon Mee Park: https://orcid.org/0000-0002-4596-6429 https://orcid.org/0000-0002-9232-746X https://orcid.org/0000-0001-9749-426X https://orcid.org/0000-0001-6372-432X https://orcid.org/0000-0002-5835-2741

\section{REFERENCES}

1. Love J, Bernard EJ, Cockeram A, et al. A multicentre, observational study of sodium picosulfate and magnesium citrate as a precolonoscopy bowel preparation. Can J Gastroenterol 2009;23:706-710.

2. Hoy SM, Scott LJ, Wagstaff AJ. Sodium picosulfate/magnesium citrate: a review of its use as a colorectal cleanser. Drugs 2009;69:123-136.

3. Suh JP, Choi YS, Lee SH. Education and imaging. Gastroenterology: acute mucosal injury of esophagus and stomach induced by sodium picosulfate/magnesium citrate for bowel preparation. J Gastroenterol Hepatol 2014;29:1571.

4. Lee DS, Kim HS, Lee SH, Jeon JH, Lee YK. A case of PICOLIGHT powder induced thermal injury of the gastric mucosa. Korean J Helicobacter Up Gastrointest Res 2014;14:58-60.

5. Seo JY, Kang KJ, Kang HS, et al. Corrosive esophagitis caused by ingestion of picosulfate. Clin Endosc 2015;48:66-69.

6. Kim GB, Hwang SY, Shin TG, et al. Upper airway obstruction resulting from acute mucosal injury induced by direct ingestion of sodium picosulfate/magnesium citrate powder. Clin Exp Emerg Med 2016;3:109-111.

7. Ze EY, Choi CH, Kim JW. Acute gastric injury caused by undissolved sodium picosulfate/magnesium citrate powder. Clin Endosc 2017;50:8790

8. Yang DH, Bang BW, Kwon KS, Kim HK, Shin YW. A case of thermal esophageal injury induced by sodium picosulfate with magnesium citrate. Case Rep Gastrointest Med 2017;2017:9879843.

9. Poley JW, Steyerberg EW, Kuipers EJ, et al. Ingestion of acid and alkaline agents: outcome and prognostic value of early upper endoscopy. Gastrointest Endosc 2004;60:372-377.

10. Hollenbach M, Tunnemann J, Struck MF, et al. Endoscopic findings and outcome in caustic ingestion of acidic and alkaline agents in adults: a retrospective analysis. Medicine (Baltimore) 2019;98:e16729.

11. Zargar SA, Kochhar R, Mehta S, Mehta SK. The role of fiberoptic endoscopy in the management of corrosive ingestion and modified endoscopic classification of burns. Gastrointest Endosc 1991;37:165-169.

12. Katz A, Kluger Y. Caustic material ingestion injuries- paradigm shift in diagnosis and treatment. Health Care Curr Rev 2015;3:152.

13. Ryu HH, Jeung KW, Lee BK, et al. Caustic injury: can CT grading system enable prediction of esophageal stricture? Clin Toxicol (Phila) 2010;48:137-142.

14. Methasate A, Lohsiriwat V. Role of endoscopy in caustic injury of the esophagus. World J Gastrointest Endosc 2018;10:274-282.

15. Tharavej C, Pungpapong SU, Chanswangphuvana P. Outcome of dilatation and predictors of failed dilatation in patients with acid-induced corrosive esophageal strictures. Surg Endosc 2018;32:900-907.

16. Chirica M, Bonavina L, Kelly MD, Sarfati E, Cattan P. Caustic ingestion. Lancet 2017;389:2041-2052.

17. Siersema PD. How to approach a patient with refractory or recurrent benign esophageal stricture. Gastroenterology 2019;156:7-10 